\title{
Current management of hypertension in hospital
}

\author{
R F HELLER, GEOFFREY ROSE
}

TABLE I-Blood-pressure recordings in the notes of patients of two general hospitals

\section{Summary \\ A study of the notes of 1784 patients new to two London hospitals found a blood-pressure recording in 1027 $(58 \%)$. Only $423(32 \%)$ of all outpatients had had a blood- pressure recording on their first visit. Of 144 patients with hypertension (systolic $160 \mathrm{~mm} \mathrm{Hg}$ or diastolic $100 \mathrm{~mm} \mathrm{Hg}$ or both) a check recording was made in $89(62 \%)$ and $18(12 \%)$ were put on treatment. We conclude that the opportunity that a hospital visit provides for blood-pressure screening is being incompletely used, and that the discovery of hypertension often does not lead to further action.}

\section{Introduction}

As part of an examination of the way in which hypertension was dealt with in one part of London we decided to study the case notes of the patients of two general hospitals. We investigated how far hospital resources were being used to detect hypertension, what action was taken when and if hypertension was discovered, and how effective was the treatment given.

\section{Patients and methods}

A total of 25547 patients were registered as new to the two hospitals in 1971. This included both inpatients and outpatients but excluded casualty and special clinic attenders. We drew a random sample of registration numbers, and then searched for the case notes. Patients aged less than 15 were excluded, leaving a sample of 1867 patients. For twelve patients the case notes could not be found, and 71 were private patients who were not studied further because of lack of information. The sample therefore comprised 1784 adult patients whose notes were examined for information relating to blood pressure. The study was performed in the first part of 1974 .

\section{Results}

Four hundred and sixty-five $(26 \%)$ of those sampled were inpatients, of whom $236(51 \%)$ were men; $1060(60 \%)$ were aged between 15 and 39 years, with 327 (18\%) aged 60 or more).

Detection of hypertension-Only 1027 of the 1784 patients $(58 \%)$ had a blood-pressure recording, $839(47 \%)$ on their first visit and 188 $\left(11_{0}{ }_{0}\right)$ on a later occasion; and $756(42 \%)$ had no recording at any time during the two to three years between their first visit and the survey. The place of presentation was the major factor determining whether blood-pressure would be recorded-only 31 inpatients $(7 \%)$ never having a blood-pressure recording as opposed to 725 outpatients $\left(55^{\circ}\right.$ ) (table I). One hundred and sixty-seven patients $(16 \%)$ had a blood-pressure recording which was defined as "hypertensive" for the purpose of this study-systolic equal to or greater than $160 \mathrm{~mm} \mathrm{Hg}$ or diastolic equal to or greater than $100 \mathrm{~mm} \mathrm{Hg}$ or both. The prevalence of hypertension rose steeply with age (table II.)

Recognition of hypertension-The 167 patients found to be hypertensive included 12 who died during their initial hospital admission,

St Mary's Hospital Medical School, London W2 1NY

R F HELLER, MD, MRCP, lecturer in epidemiology

GEOFFREY ROSE, DM, FRCP, professor of epidemiology and preventive medicine

\begin{tabular}{|c|c|c|c|c|}
\hline Group & No & $\begin{array}{l}\text { BP recorded } \\
\text { initially }(\%)\end{array}$ & $\begin{array}{l}\text { BP recorded } \\
\text { later }\left({ }^{\prime \prime}\right)\end{array}$ & $\begin{array}{l}\text { BP never } \\
\text { recorded ("\%) }\end{array}$ \\
\hline $\begin{array}{l}\text { All inpatients } \\
\text { Outpatients: }\end{array}$ & 465 & $416(89)$ & $18(4)$ & $31(7)$ \\
\hline Medical & 263 & $180(68)$ & $18(7)$ & $65(25)$ \\
\hline Surgical & 466 & $34(7)$ & $105(23)$ & $327(70)$ \\
\hline Antenatal & 203 & $197(97)$ & $4(2)$ & $2(1)$ \\
\hline Others & 386 & $12(3)$ & 43 (11) & $331(86)$ \\
\hline All outpatients & 1318 & $423(32)$ & 170 (13) & $725(55)$ \\
\hline All patients* & 1783 & $839(47)$ & 188 (11) & $756(42)$ \\
\hline
\end{tabular}

${ }^{*}$ Information not available for one patient.

TABLE II-Prevalence of hypertension* according to age and sex among $1026+$ patients with a blood-pressure recording. Results expressed as proportions of patients

\begin{tabular}{|c|c|c|c|}
\hline Age (years) & Men & Women & Both \\
\hline $\begin{array}{c}15-39 \\
40-59 \\
60\end{array}$ & $\begin{array}{ll}11 & 164\left(7{ }^{\prime}{ }^{\prime}\right) \\
32 & 125\left(26^{\prime \prime}\right) \\
46 & 110\left(42^{\prime \prime}\right)\end{array}$ & $\begin{array}{c}94423\left(2 "{ }^{\prime \prime}\right) \\
2491\left(26 "{ }^{\prime \prime}\right) \\
45113\left(40 "{ }^{\prime}\right)\end{array}$ & $\begin{array}{l}20 / 587\left(3{ }^{\prime}{ }^{\prime}\right) \\
56 / 216\left(26{ }^{\circ}{ }^{\prime}\right) \\
91 / 223\left(41{ }^{\prime}\right)\end{array}$ \\
\hline All ages & $89399\left(22{ }^{\prime \prime}.\right)$ & $78627\left(12^{\prime \prime}{ }_{11}\right)$ & $1671026\left(16{ }^{\prime \prime}{ }_{0}\right)$ \\
\hline
\end{tabular}

* Systolic $160 \mathrm{~mm} \mathrm{Hg}$ or diastolic $100 \mathrm{~mm} \mathrm{Hg}$ or both.

tAge unknown for one patient.

leaving 155 whose notes could be examined to determine whether further action had been taken on their hypertension. The general practitioner was informed about the blood-pressure in $110(71 \%)$ of these cases, but in $34(22 \%)$ the general practitioner was not informed and the blood pressure was not subsequently recorded. In 11 patients hypertension was detected at their first and only clinic visit, so further action on 144 patients who attended hospital again was examined. Eighty-nine of these patients $(62 \%)$ had another blood-pressure measurement-in 47 this was no longer raised and another 18 were put on treatment. So of the 144 hypertensive patients $65(45 \%)$ were either later found to be normotensive or were started on treatment, leaving $79\left(55^{\circ}\right)$ for whom the issue was apparently not resolved. The higher the level of blood pressure, the more likely it was to be checked later and treatment to be started (table III), but there was little difference according to the age or sex of the patient.

Treatment of hypertension-We examined the degree of control of blood pressure in the 18 patients given treatment for hypertension. Excluding the first two recordings on each patient, and the hospital recordings of those who presented first as inpatients, there were 144 blood-pressure records in the notes of these 18 patients. The diastolic level was equal to or greater than $100 \mathrm{~mm} \mathrm{Hg}$ in $98(68 \%)$ and equal to or greater than $115 \mathrm{~mm} \mathrm{Hg}$ in $31(21 \%)$ of the recordings.

In view of the small numbers of patients identified to be on treat-

TABLE III-Number $(\%)$ of hypertensive patients having repeat blood-pressure $(B P)$ recordings and hypotensive treatment

\begin{tabular}{|c|c|c|c|}
\hline Initial $\mathrm{BP}(\mathrm{mm} \mathrm{Hg})$ & $\begin{array}{l}\text { No attending } \\
\text { again }\end{array}$ & $\begin{array}{l}\text { BP recorded } \\
\text { again }\end{array}$ & $\begin{array}{c}\text { Hypotensive } \\
\text { treatment }\end{array}$ \\
\hline $\begin{array}{c}\text { Systolic: } \\
160-179 \\
180-199 \\
200\end{array}$ & $\begin{array}{l}66 \\
28 \\
27\end{array}$ & $\begin{array}{l}32\left(48^{\circ}{ }_{0}\right) \\
21\left(75^{\prime \prime}\right) \\
21\left(78_{0}{ }_{0}\right)\end{array}$ & $\begin{array}{l}5\left(8^{\circ}{ }_{0}\right) \\
3\left(11_{0}^{\circ}\right) \\
8\left(30_{0}^{\circ}\right)\end{array}$ \\
\hline All 160 & 121 & $74\left(61{ }^{\circ} 0\right)$ & $16\left(13{ }_{0}\right)$ \\
\hline $\begin{array}{c}\text { Diastolic: } \\
100-109 \\
110-119 \\
120\end{array}$ & $\begin{array}{l}42 \\
22 \\
21\end{array}$ & $\begin{array}{l}22\left(52^{\prime \prime}{ }^{\prime \prime}\right) \\
20\left(91 "{ }^{\prime \prime}\right) \\
18\left(86^{\prime \prime}{ }^{\prime}\right)\end{array}$ & $\begin{array}{c}3(7 \%) \\
3(14 \%) \\
10(48 \%)\end{array}$ \\
\hline All 100 & 85 & $60\left(71{ }^{\circ}\right.$ o) & $16\left(19{ }^{\circ}{ }_{0}\right)$ \\
\hline $\begin{array}{l}\text { All: systolic } 160 \text { or } \\
\text { diastolic } 100 \text { or both }\end{array}$ & 144 & $89\left(62{ }^{\prime \prime}\right)$ & $18(12 \%)$ \\
\hline
\end{tabular}


ment, a separate study was performed to examine the degree of control achieved in 85 patients receiving treatment for hypertension at one of the hospitals. ${ }^{1}$ The patients were all those receiving treatment for hypertension among those attending any of nine medical outpatient clinics during one week in December 1972. Their blood-pressure recordings on treatment over the preceding two years (or part of that time) were noted and followed up for the next two-year period. Over the four-year period there were 1272 blood-pressure recordings, of which $758(60 \%)$ were at levels equal to or greater than $100 \mathrm{~mm} \mathrm{Hg}$.

\section{Discussion}

Both the general hospitals we studied are in London, one having a long history as a teaching hospital and the other having relatively recently joined the teaching group. They were chosen to see whether there were any differences in their management of hypertension due to different traditions and staff. Few differences were found, suggesting that there might be similar findings in other hospitals.

The study showed that these hospitals were not acting effectively as screening centres for hypertension. Most outpatients escaped without a blood-pressure recording unless they had attended an antenatal or medical clinic. Some outpatients in surgical departments had their blood pressure recorded but usually only when subsequently admitted to hospital (table I). Completing the hospital picture, a separate study of the casualty departments ${ }^{1}$ showed that $73^{\circ}{ }^{\circ}$ of 155 adult patients who were admitted from casualty had a blood-pressure recording made there but that only $15^{\circ}$ " of the 962 who were not admitted had one. Thus the opportunity of screening a large proportion of the population for hypertension is being missed, as a recent population survey' found that over half of a sample of adults living in the study area had visited hospital in a three-year period.

There have been no comparable studies reported in Britain. In the USA, however, one study ${ }^{3}$ found a blood-pressure recording in only $74^{\circ}$ of doctors' inpatient notes, another ${ }^{4}$ found a recording in $43^{\circ}{ }_{0}$ of outpatient notes, and a third ${ }^{5}$ found $14^{\circ}{ }^{\circ}$ of casualty attenders to have a blood-pressure recording in their notes. These figures are similar to our findings, although the proportion of inpatients with a blood-pressure recording in our study was higher. Nevertheless, the coding was designed to include any blood-pressure measurement in the notes, even if it was not performed on admission.

Our study also shows that detection of hypertension often did rot lead to further action. The general practitioner was informed in only 110 cases $\left(71^{\circ}{ }_{10}\right)$, and in $34\left(22^{\circ}{ }^{\circ}\right)$ the hypertension seems to have been completely ignored. The blood pressure was either found to be normal later or was treated in only $65\left(45^{\circ}{ }_{0}\right)$ of the hypertensive patients. This compares with an American study ${ }^{6}$ which claimed an adequate follow-up of $98^{\circ}$ ". of randomly selected outpatients with a diastolic pressure of $90 \mathrm{~mm} \mathrm{Hg}$ or more.

Most of the patients whose hypertension was ignored completely had blood-pressure levels close to the cut-off points chosen for this study. There is little doubt about the risks incurred by having a blood-pressure of around $160 \mathrm{~mm} \mathrm{Hg}$ systolic or $100 \mathrm{~mm} \mathrm{Hg}$ diastolic, ' but trials are still in progress to assess the benefits of treatment at these levels. ${ }^{*}$ Even among those for whom treatment has definitely been shown to be effective, however, there were patients whose hypertension received no further attention.

Although the degree of blood-pressure control achieved in the patients started on treatment was less than ideal, it conforms with published figures from other hospital series in which between $40^{\circ}{ }_{0}$ and $60^{\circ}{ }^{\circ}$ of unselected hypertensive patients have had their diastolic pressure controlled to $100 \mathrm{~mm} \mathrm{Hg}$ or below. ${ }^{9} 10$ Comparisons are difficult to make, however, since differences in severity of hypertension between series are directly related to the ease of control on treatment. ${ }^{1}$

This work formed part of an MD thesis by $\mathrm{RFH}$, accepted by London University.

\section{References}

${ }^{1}$ Heller, R F, MD thesis, London University, 1976

${ }^{2}$ Heller, R F, British fournal of Preventive and Social Medicine, 1976, 30, 268

${ }^{3}$ Frohlich, E D et al, fournal of the American Medical Association, 1971, 218, 1036.

+ Mroczek, W J, Martin, M, and Finnerty, F A, fournal of the American Medical Association, 1975, 231, 1264.

5 Mroczek, W J, Clinical Research, 1972, 20, 477.

${ }^{6}$ Goetzl, E J, et al, Annals of Internal Medicine, 1973, 78, 481.

' Society of Actuaries, Build and Blood Pressure Study', vols 1 and 2, Chicago, 1959.

${ }^{8}$ Peart, W S, Clinical Science and Molecular Medicine, 1973, 45, 67s.

9 Stuart, K L, Maciver, C, and Nicholson, J A, British Medical fournal, $1972,2,21$

10 Zacharias, F J, et al, American Heart fournal, 1972, 83, 755.

(Accepted 1 April 1977)
St Mary's Hospital Medical School, London W2 1NY

R F HELLER, MD, MRCP, lecturer in epidemiology

GEOFFREY ROSE, DM, FRCP, professor of epidemiology and preventive medicine pressure recording in a five-year period. Proportions varied between $4 \%$ and $36 \%$ in the different practices. The blood pressure was raised (systolic $160 \mathrm{~mm} \mathrm{Hg}$ or diastolic $100 \mathrm{~mm} \mathrm{Hg}$ or both) in 74 patients $(45 \%)$ whose blood pressure had been recorded, and another recording had subsequently been made in $45(61 \%)$ of these patients. Fifteen $(21 \%)$ of those with hypertension had not had a blood-pressure recording during the five years before the study. Tranquillisers or sedatives were the commonest drugs used in the treatment of hypertension. As in a study of the management of hypertension in hospital, ${ }^{\prime}$ opportunities provided by visits to the general practitioner were not commonly used for blood-pressure screening, and the discovery of hypertension often did not lead to further action. 